\title{
砕波帯内における流れと流体の乱れに関する考察 \\ Mean Flow and Turbulence in a Surf Zone
}

\author{
渡部 靖憲”・森 憲広”黒木 幹男“・佐伯 浩” \\ Yasunori Watanabe, Norihiro Mori, Mikio Kuroki and Hirosi Saeki
}

Three-dimensional fluid velocity field in a surf zone was experimentally investigated to obtain spatial characteristics of mean flow, such as return current, and turbulence flow caused by wave breaking. It is possible that three-dimensional organized vorticities, generated after breaking, indirectly affect to mean flow and induce three-dimensional steady flow. In two-dimensional wave flume, return current contributes three-dimensionality of fluid motion in a surf zone. The effect of return current to a front bore is also investigated by the particle image velocimetry.

Keywords: breaking waves, return current, turbulence, three-dimensional velocity field

\section{1.はじめに}

砕波帯内では様々なスケールの流体運動か存在しそれらは互いに影響しあいながら複雑な速度場を構成してい る。その代表的な例として、離岸流、向岸流等の流れと砕波過程における乱れとの関係は岸沖漂砂過程での砂の 巻き上け、移動に大きな影響を与えられると考えられる。一般に岸沖方向の漂砂量は、砕波形態の違いによって も異なることからも砕波による乱れと、直接砂移動に関係する岸沖方向流れとが影響しあうメカニズムを調へる ことは重要である。

砕波帯内の問題は、砂移動の観点において、戻り流れや海浜流等の時間平均流に関する研究(例えば、岡安 ら,1980)之砕波時に発生する衝撃的な流体力による瞬時の乱れに関する研究(例えば、F.C.K. Ting et al., 1995)か数多 くなされてきた。これらの流速場は、密接に関係し合うと考えられ、時間平均流か砕波によって引き起こされる 乱れ及び周期的な波動の主流流速との関係を結びつける必要がある。また、乱流は一般的に 3 次元的となり、砕 波後の乱流場も同様に高歪みの 3 次元性を持つ組織的渦構造を伴うことが確認されており(日野ら, 1984)、この領 域における 3 次元的な平均流及ひ乱流の特性を調へることは砕波過程のメカニズムを知るためや砕波帯内の流速 モテルをつくるうえで有効なデータとなるはずである。特に砕波帯内の実験において実験室規模の 2 次元水槽は 特殊な条件のもとで実海域を考えた場合に限り対応すると考えられ、その影響を明らかにする必要がある。

本研究では、実験水槽の両端を結ふ澴流パイプを設置することによって岸沖方向の流れを制御することによっ て、戻り流れが砕波帯内の流速場へ与える影響及びその 3 次元性について調へていく。

\section{2 .実験装置}

実験水槽は、全長 $24 \mathrm{~m} 、$ 幅 $60 \mathrm{~cm}$ 二次元水槽であり、ピストン式造波装置が設置してある。造波装置の前面に1/ 10 勾配で延長 $1 \mathrm{~m}$ 傾斜板を設置し、5mの水平部をはさみ延長 $12 \mathrm{~m}$ 、勾配1/600斜面を設定し水路終端に透過性消波 工を設置してある。計測機械として入反射分離のために水平部に容量式波高計 2 本、砕波帯内に位相平均のため の波高計及び流速計を設置した。また、戻り流れ及ひ砕波後のset upを制御するために水路の両端を結つ海化ビニー ルパイプを底面下に埋設したこの還流パイプの蓋を開閉することにより流れを調節する。流速計は 3 次元アコー

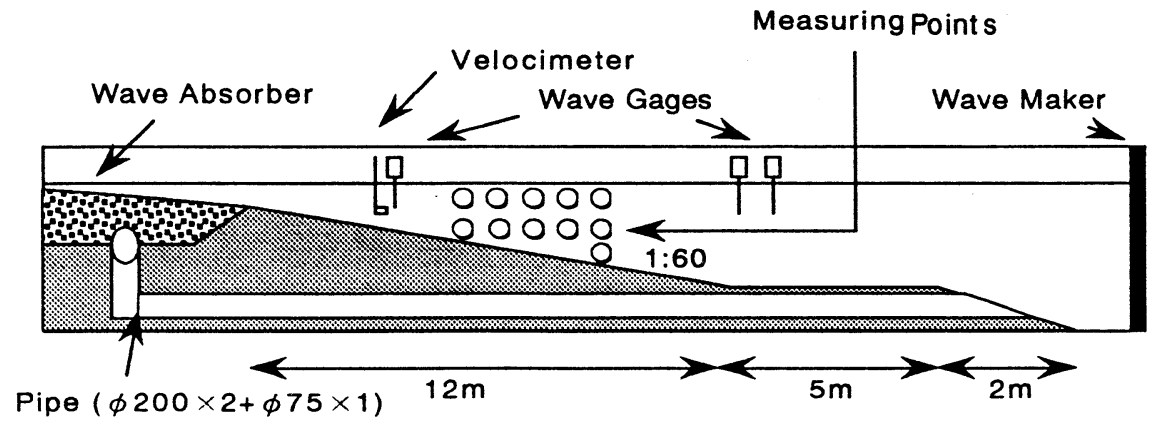

図 1 実験装置

* 学生会員 北海道大学大学院 (060 札幌市北区北13条西8丁目)

** 正会員 北海道大学工学部 
スティックドップラー流速計を用いた。この流速計は、LD.V.と比較して精度は高くないが容易に 3 次元流速を計 測することかできる。流速は図 1 に示すように、鉛直方向に $2 \mathrm{~cm}$ 間隔、水平方向に砕波前は $4 \mathrm{~cm}$ 間隔で砕波後は $2 \mathrm{~cm}$ 間隔で計測した。また、流速及び水位変動の データはサンプリング間隔40msecで計測されて いる。

画像処理による流速の計測のために、直径2$3 \mathrm{~mm}$ 、比重1.005の白色中立粒子を水槽内に混入 させ、その動きを高速ビデカメラにより毎秒 125コマで撮影した。なお、この画像は256色グ レイスケールにデジタル化された $320 \times 240$ 画素 に変換し解析を行った。この時の解像度は約 $1 \mathrm{~mm} / \mathrm{pixel}$ であった。

本流速実験では周期1.2秒、沖波波高9 $\mathrm{cm}$ の波 を扱った。また、このときの砕波形態はspilling breakerであった。

\section{3.基礎方程式}

Navier-Stokes式中の流速及び圧力を次のように時 間平均量、周期的変動量と不規則変動量に分け平 均すると(1)-(3)で示されるそれぞれの平均及び変 動流速に関する方程式が得られる。

$u_{i}=U_{i}+\tilde{u}_{i}+u_{i}^{\prime}, p=P+\tilde{p}+p^{\prime}$

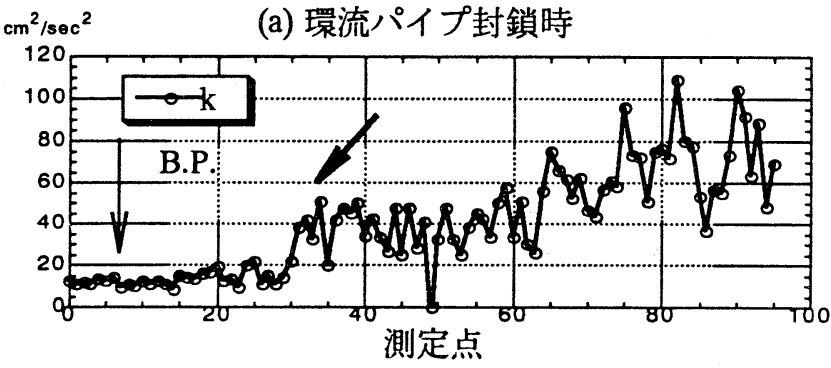

$\mathrm{cm}^{2} / \mathrm{sec}^{2} \quad$ (b) 環流パイプ開放時

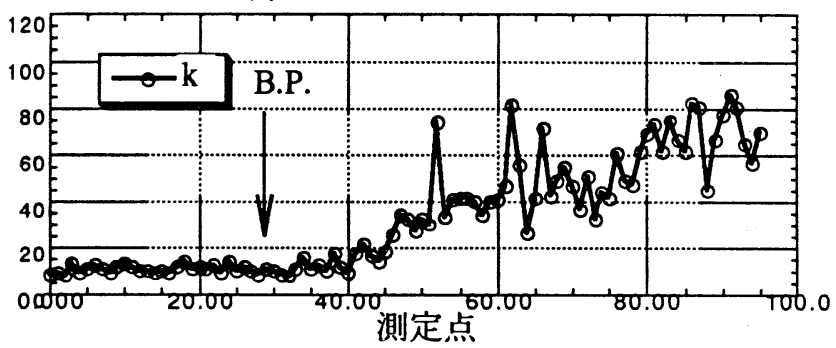

図 2 乱れエネルギー分布

ここで大文字は時間平均量、 は周期性を持つ変動、'は不規則な変動を表す。

$U_{j} \frac{\partial U_{i}}{\partial x_{j}}=\frac{\partial}{\partial x_{j}}\left(-\frac{P}{\rho} \delta_{i j}+v \frac{\partial U_{i}}{\partial x_{j}}-\overline{u_{i}^{\prime} u_{j}^{\prime}}-\overline{\tilde{u}_{i} \tilde{u}_{j}}\right)$

$\frac{\partial \tilde{u}_{i}}{\partial t}+U_{j} \frac{\partial \tilde{u}_{i}}{\partial x_{j}}+\tilde{u}_{j} \frac{\partial U_{i}}{\partial x_{j}}=\frac{\partial}{\partial x_{j}}\left(-\frac{\tilde{p}}{\rho} \delta_{i j}+v \frac{\partial \tilde{u}_{i}}{\partial x_{j}}+\left(\overline{\tilde{u}_{i} \tilde{u}_{j}}-\tilde{u}_{i} \tilde{u}_{j}\right)-\left(\left\langle u_{i}^{\prime} u_{j}^{\prime}\right\rangle-\overline{u_{i}^{\prime} u_{j}^{\prime}}\right)\right)$

$\frac{\partial u_{i}^{\prime}}{\partial t}+\left(U_{j}+\tilde{u}_{j}\right) \frac{\partial u_{i}^{\prime}}{\partial x_{j}}+u_{j}^{\prime} \frac{\partial\left(U_{i}+\tilde{u}_{i}\right)}{\partial x_{j}}=\frac{\partial}{\partial x_{j}}\left(-\frac{p^{\prime}}{\rho} \delta_{i j}+v \frac{\partial u_{i}^{\prime}}{\partial x_{j}}+\left(\left\langle u_{i}^{\prime} u_{j}^{\prime}\right\rangle-u_{i}^{\prime} u_{j}^{\prime}\right)\right)$

ここて、一は 時間平均、〈〉は位相平均を表 す。

本研究では、実験で得られた流速テータを水 位変動のゼロアップクロスを基準にした約30波 の位相平均との変動を乱れとして扱う。気泡混 入に伴う欠足デー夕に関しては、そのデータを 削除し、前後のデータより補間した。しかし、 しきい值に満たない気泡の影響を受けたデタ に関しては解析対象のデータとなってしまって いる。

\section{4 .実験結果}

図 2 は、乱れエネルギー $\mathrm{k}\left(=u_{i} u_{i}^{\prime} / 2\right)$ の時間平均 の空間分布を示している。(a)は環流パイプを閉 鎖した時の結果、(b)は環流パイプを開放したと きの結果であり、両者とも静水位以下 $4 \mathrm{~cm}$ での 値を表す。砕波後、乱れエネルギーは(a)の場合

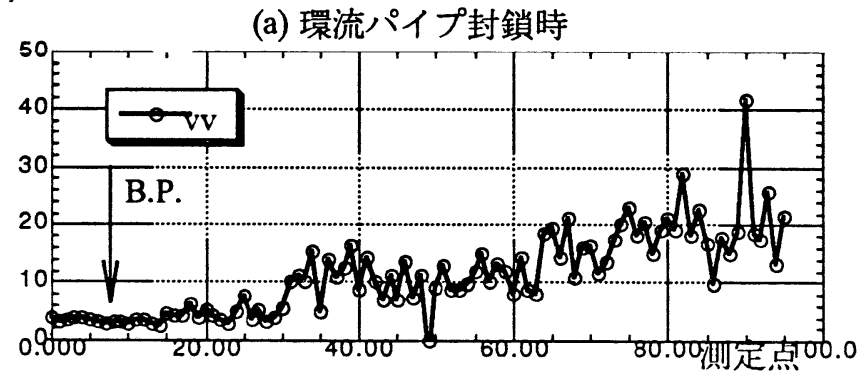

(b) 環流パイプ開放時

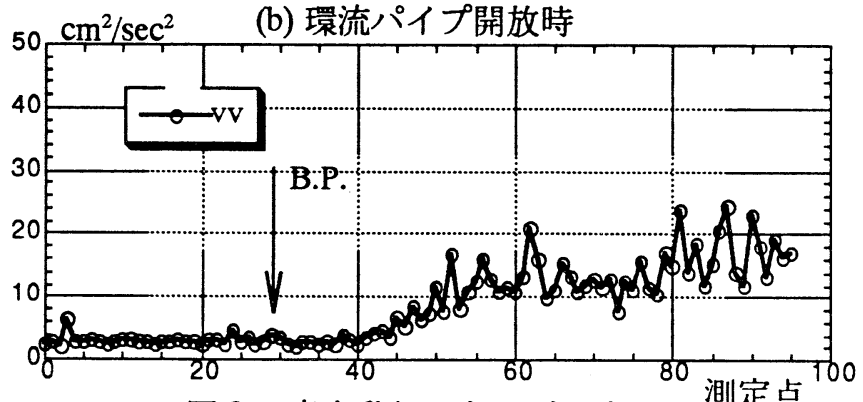

図3 直交乱れエネルギー成分 


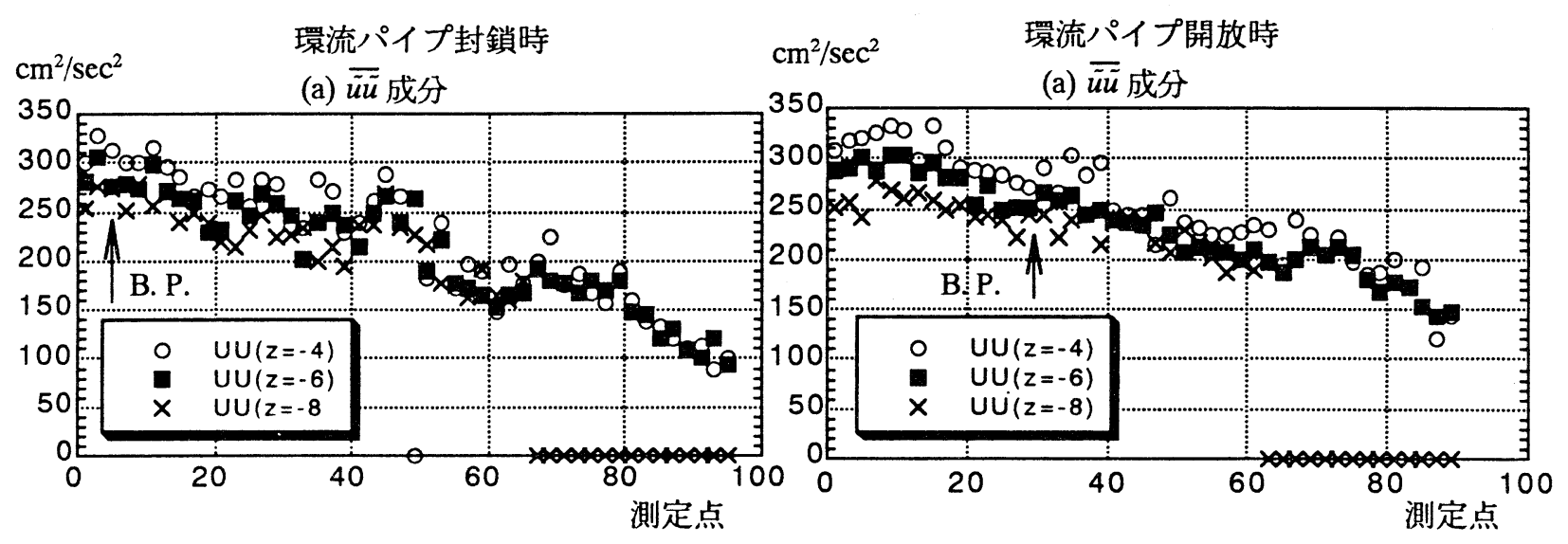

$\mathrm{cm}^{2} / \mathrm{sec}^{2}$

(b) $\overline{\tilde{v} \bar{v}}$ 成分

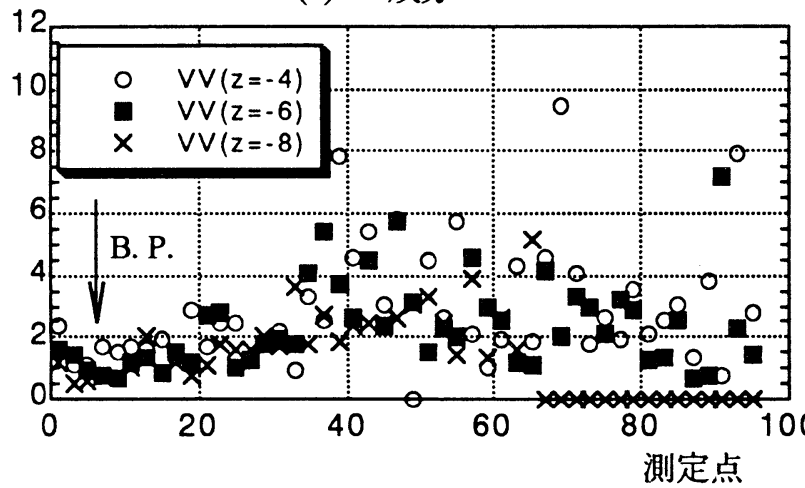

$\mathrm{cm}^{2} / \mathrm{sec}^{2}$

(b) $\overline{\bar{v} \bar{v}}$ 成分
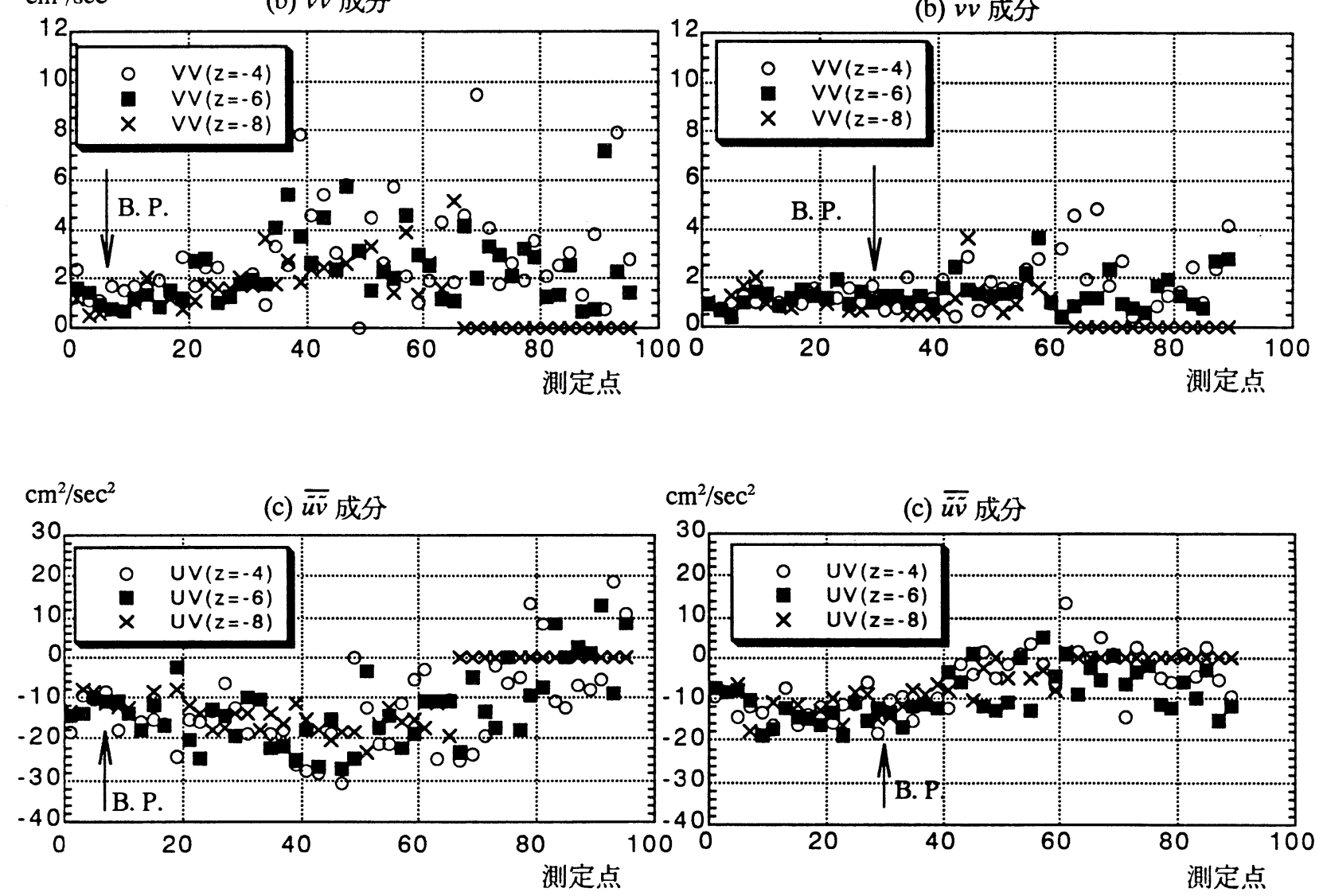

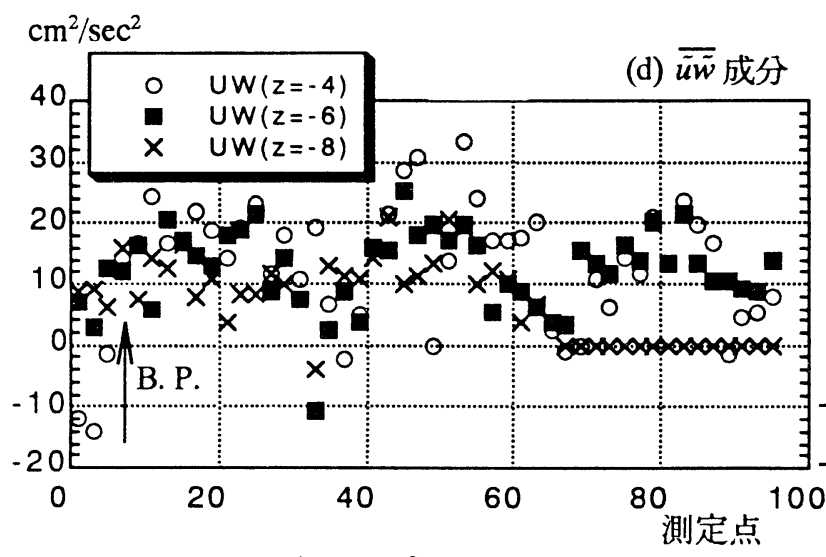

図4 環流パイプ封鎖時の周期的変動 レイノルズストレス

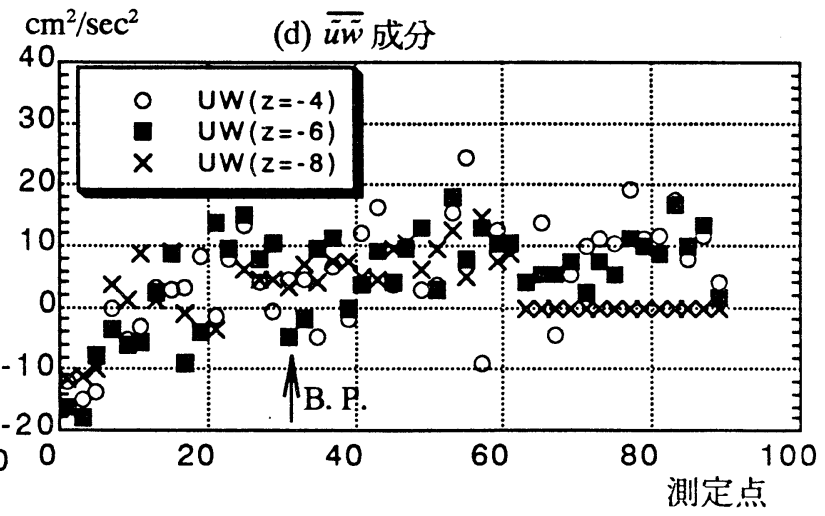

困5 環流パイプ開放時の周期的変動 レイノルズストレス 
矢印のあたりで急激に増加し、その後徐々に増加している。一方(b)は、砕波後ゆるやかに乱れエネルギーが増加 し、ゆっくりと乱れが生成されていると考えられる。(3)式で考えれば、左辺2項目の移流項によって乱れか輸送さ れて砕波点之乱れの発達する位置がずれること、また戻り流れの存在によって鉛直方向の流速勾配がトラフレベ ル付近を境にして急になるため3項目を中心とした移流効果により乱れの発達の度合いか湾わってくると考えられ る。また、図 3 に示すように、3 次元的な乱流場になっている事を表すい成分(直交乱れ成分)も同様な傾向を示し ており、砕波帯内の流体運動の 3 次元性にも岸沖方向の流れが影響している可能性があるといえる。その他の不 規則乱れに関するレイノルズストレス成分についてもほぼ同様な空間勾配をもつ単調増加の傾向がみられた。

図4、5はそれぞれ環流パイプ閉 鎖時及び開放時の周期的変動レイノ ルズストレス成分 $\left(\overline{\tilde{u_{i}}} \tilde{u}_{j}\right)$ の空間分布 を示した一例である。これらはラ ティエーションストレスに関わるも のである。(a)立花成分の環流パイプ封 鎖時の結果が、空間勾配か若干急で ある以外は両者について明確な違い がみられない。しかし、(b) $\overline{\bar{v}} \bar{v}$ (直交 流速成分）は、(a)とはオーダー自体 が異なっているとはいえ、環流パイ プの封鎖之開放でその絶対値や広が り具合が異なっており、岸沖方向の 流れの存在か砕波帯内の流速場の 3 次元性に寄与しているのがここから もわかる。また(c) $\overline{\tilde{u} \tilde{u}}$ 及び(d) $\overline{\bar{u} \tilde{w}}$ 成分 を比較してみると、環流パイプの封 鎖亡開放の結果は定量的、定性的に 異なった特性を持っているのがわか $\mathrm{cm} / \mathrm{sec}$

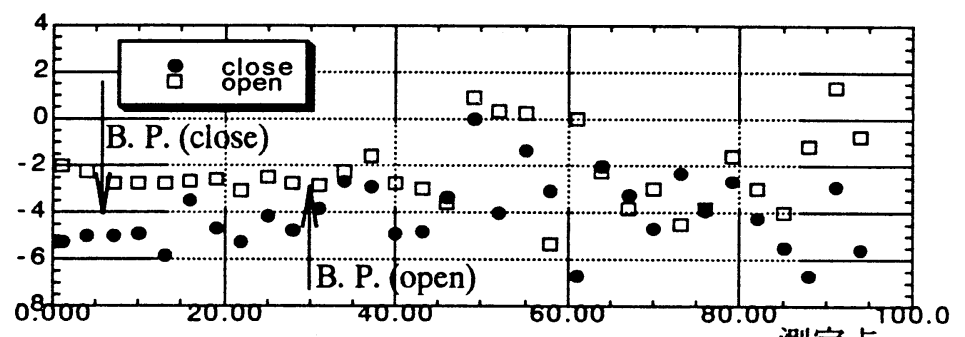

図 6 時間平均水平流速の空間分布 測定点

$\mathrm{cm} / \mathrm{sec}$

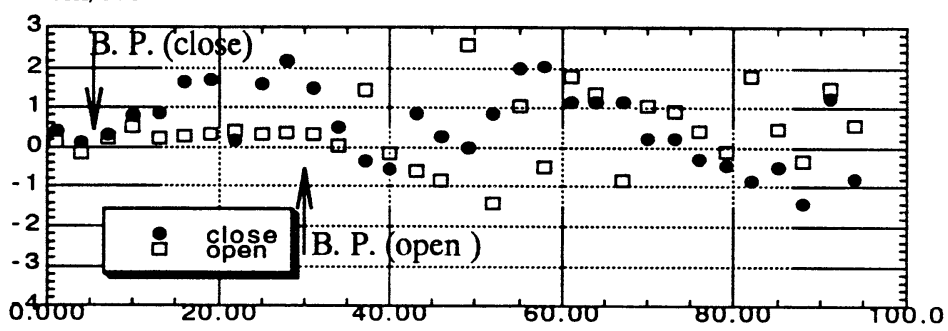

図 7 時間平均直交流速の空間分布 測定点 る。また、これらの成分が、両者で

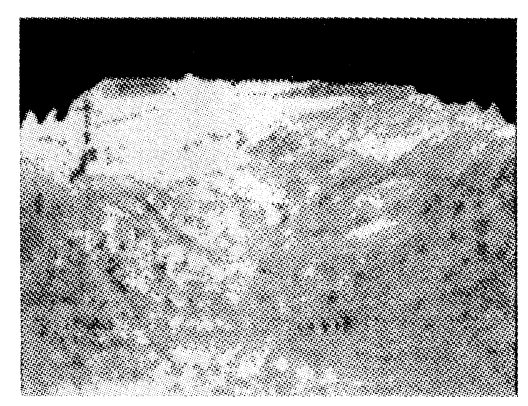

図 8 砕波時の水平流速分布 (spilling breaker) 環流パイプ封鎖

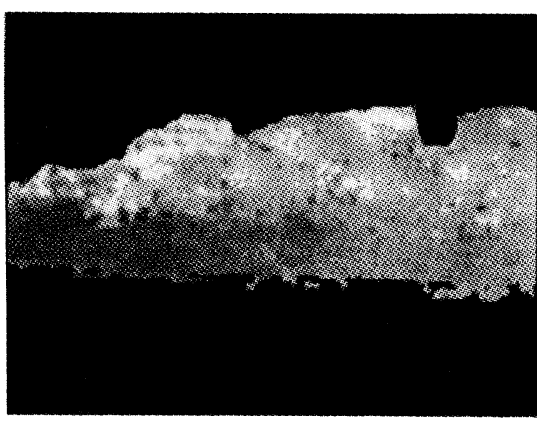

図10 砕波後の水平流速分布 (plunging breaker) 図11 環流パイプ封鎖

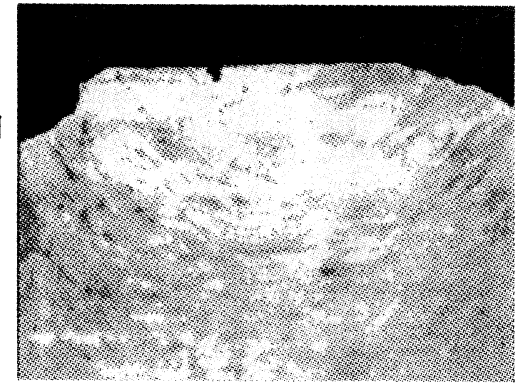

図 9 砕波時の水平流速分布 (spilling breaker) 環流パイプ開放

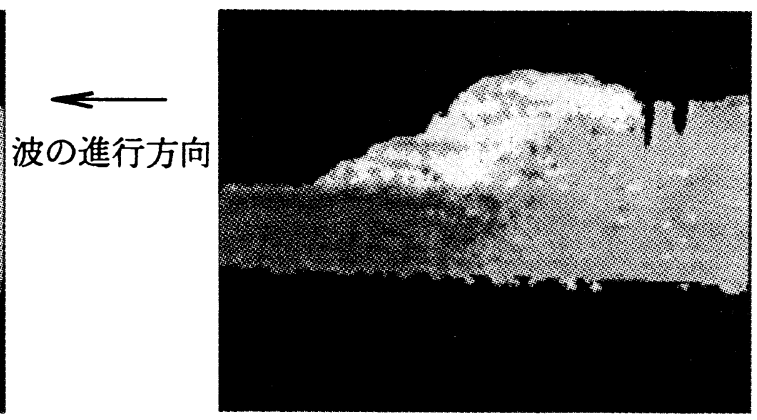

砕波後の水平流速分布 (plunging breaker) 環流パイプ開放 
異なる波長をもって空間的に振動しているのが特徴的である。また、環流パイプ封鎖時の方が開放時よりもこれ らの成分の値及び空間勾配が大きことは、砕波帯内の流速場をモテル化するとき、戻り流れによる波動の主流 速成分への寄与を 3 次元性を含めて考慮すべきであることを意味するだけではなく、2次元水槽内における砕波 後の流速場が 3 次元性を示しやすい条件になっていることを意味し、実験水槽におけるこれらの特性と実海域之 の対応に注意する必要がある。一方、これらの結果は、流れの存在か砕波後の周期的に変動する主流の流速場を 変えているだけでなく、(1)式から明らかなように主流が変わることによる周期的変動レイノルズストレスの効果 として流れ自身の時間平均流速場も変えられる。

図 6、7は、それぞれ静水位以下 $4 \mathrm{~cm}$ はおける水平流速 $\mathrm{u}$ 、直交流速 $\mathrm{v}$ の時間平均量の空間分布である。砕波 後、水平及ひ值交流速力変化しており、図 4、5で考察した主流の変化の時間平均流速場への寄与を表している。 また、直交流速か空間的に振動する結果が表れており、現象としては興味深い。日野ら(1984)か指摘したような砕 波後の3次元的な組織的洞構造が、2 次元水槽内のスケールの䂶波に対してその効果として 3 次元的な定常循環流 が発生している可能性がある。

図2、3の不規則乱れレイノルズストレスが発達し始める位置は、周期的変動レイノルズストレスや時間平均 流速が変動し始める位置とはズレがあるのがわかる。これは、砕波直後において小さなスケールの不規則乱れは 直接時間平均流速に影響を与えるのではなく、周期的に変動する主流を変化させ、間接的に時間平均流速の変動 に寄与する。このとき、時間平均流を変化させるのは、砕波によるクレスト付近の渦がトラフレベル以下の流体 内部に到達している必要はない。このフロントの渦が十分に発達していくと周期的に変動する主流の水平流速変 動エネルギー $(\overline{\bar{u} \tilde{u}})$ が急速に減少しだすのがわかる。

これらの結果をもとに砕波後の瞬時流速の空間分布を考察していく。図8、9は同一諸元の波に対するそれぞ れ環流パイプ閉鎖時及び、開放時の砕波直後の水平流速分布を示したものである。これは渡部ら(1995)之同様な画 像処理方法によるもので、明色が正の流速を暗色が負の流速を示す。これらによると環流パイプ封鎖洔の方が、 波のフロント付近に速い流速が集中している様子がわかる。この時の主流流速の分布の違いは、(2)式の左辺の効 果と考えられ、時間平均流の違いによる砕波点の移動にも関係する。フロント内の大渦は、レイノルズストレス として、砕波後の流速場を変化させる。

図10、11は、周期2.4秒、砕波波高 $14 \mathrm{~cm}$ 、砕波水深 $15 \mathrm{~cm}$ の波における砕波点より約 $2 \mathrm{~m}$ 岸側の観測点における水平 流速分布を示している。このときの底面勾配は130であり砕波形態はplunging breakerであった。環流パイプ封鎖時 はボア状のフロント部分が内部流速の伝達よりもかなり前方へ進行している。また、流れの存在によって内部流 速の鉛直方向の勾配が大きくなっているのがわかる。この結果は前述した移流効果による乱れの輸送に影響して いると考えられる。また、図12に示す環流パイプ封鎖時の鉛直流速分布から、ボア状フロント直下で空間的に振 動するような鉛直流速を確認することができる。 plunging breakerの場合、ジェットの突っ込み直後に非常に大きな 渦を伴いながら非常に複雑な流速場になるため、この突っ込み時における流れの影響は確認することかできなかっ たが、ボアの進行に伴ってある程度エネルギーが弱まった段階ではやはり戻り流れが影響しているのが確認でき た。

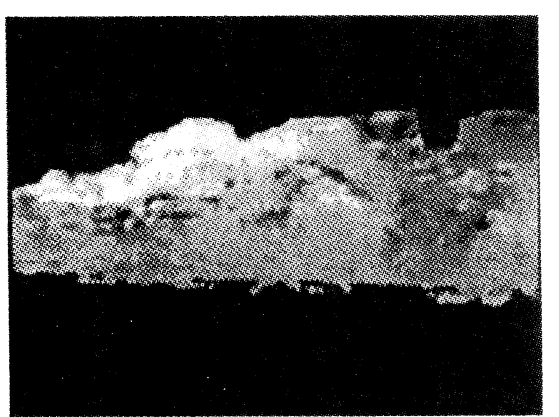

図12 砕波後の鉛直流速分布 (plunging breaker) 環流パイプ封鎖

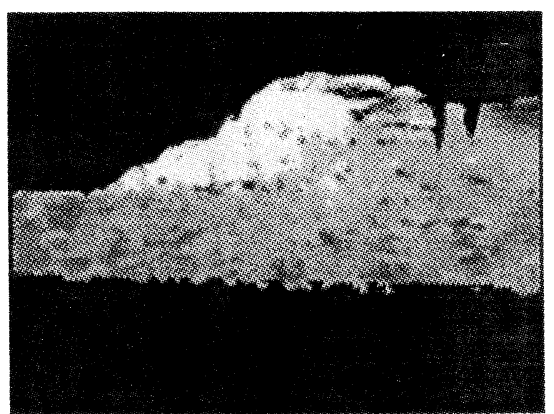

図13＼cjkstart砕波後の鉛直流速分布 (plunging breaker) 環流パイプ開放 


\section{5. 結論}

(1)砕波帯内の流速場を実験的に調へ、流れか乱れ及び周期的主流流速に与える影響とそのメカニズムを考察した。 (2)流れの制御のために設置した環流パイプの封鎖した結果と開放した結果を比較し、2次元水槽では戻り流れが 流速場の 3 次元性に影響を与えていることがわかった。また、波の伝達に対して直交する方向の成分が、環流パ イプの封鎖した場合と開放した場合で異なる波長をもって空間的に振動しているのか特徴的である。砕波帯内の 流速場をモテル化するとき、戻り流れによる波動の主流流速成分への寄与を 3 次元性を含めて考慮すべきである ことを意味するだけではなく、2 次元水槽内における砕波後の流速場が 3 次元性を示しやすい条件になっている ことを意味し、実験水槽におけるこれらの特性と実海域との対応に注意する必要がある。

(3)砝波後の3次元的な組織的渦構造が、2 次元水槽内の䂶波に対して、その効果として 3 次元的な定常偱環流か溌 生している可能性がある。砕波直後において砕波後の小さなスケールの不規則乱れは直接平均流速に影響を与え るのではなく、周期的に変動する主流を変化させ、間接的に時間平均流速の変動に寄与する。

(4)画像処理による流速の計測結果より次の結果を得た。時間平均流速及びその勾配の違いにより環流パイプ封鎖 時の方が砕波時の波のフロント付近に速い流速が集中する。フロント内の大渦は、レイノルズストレスとして、 砕波後の流速場を変化させる。砕波後のボア状のフロントが進行している状態において、環流パイプ封鎖時はボ ア状のフロント部分が内部流速の伝達よりもかなり前方へ進行している。また、流れの存在によって内部流速の 鉛直方向の勾配が大きくなっている。この結果は移流効果によって乱れの輸送に影響していると考えられる。

\section{参考文献}

渡部靖憲・細川裕希・佐伯浩, 砕波時の戻り流れの内部流速場への影響について, 海洋開発論文集, Vol. 11, pp.19-24. 渡部靖憲・佐伯浩, 画像処理による砕波帯内の運動機構に関する考察, 海岸工学論文集第42巻, pp. 116-120.

渡部靖憲・森憲広・佐伯浩, 砕波帯内における流体の乱れ特性に関する研究, 土木学会北海道支部論文報告集, 第52 号(B), pp.260-265.

岡安章夫・柴山知也・堀川清司 ; 砕波帯内二次元定常流速場の推算に関する考察, 第33回海岸工学論文集, pp. 116120.

日野幹雄・灘岡知夫・小俣篤, 砕波帯内の乱れの組織的渦構造と水粒子運動について, 第36回海岸工学論文集, pp.15.

F. C. K. Ting, J. T. Kirby, Observation of undertow and turbulence in a laboratory surf zone, Coastal Engineering, pp.51-80, 1994

F. C. K. Ting, J. T. Kirby, Dynamics of surf-zone turbulence in a strong plunging breaker, Coastal Engineering, pp. 177-204, 1995 